\title{
Selection strategies for growth characters and rubber yield in two populations of rubber trees in Brazil
}

\author{
Cecília Luzia Dourado ${ }^{\mathrm{a}, *}$, Marcela Aparecida de Moraes ${ }^{\mathrm{b}}$, Patrícia Ferreira Alves ${ }^{\mathrm{c}}$, \\ Thaisa Yuriko Kuboyama Kubota ${ }^{c}$, Janaína Rodrigues da Silva ${ }^{c}$, Juliana Prado Moreira ${ }^{c}$, \\ Alonso Ângelo da Silva ${ }^{c}$, José Cambuim ${ }^{c}$, Paulo de Souza Gonçalves ${ }^{\mathrm{d}}$, \\ Mario Luiz Teixeira de Moraes ${ }^{\mathrm{c}}$ \\ a Universidade do Estado de Mato Grasso/UNEMAT, CP 08, Rua Prof. Dr. Renato Figueiro Varella, Nova Xavantina, Mato Grosso State, 78690-000, Brazil \\ ${ }^{\mathrm{b}}$ Faculdade de Filosofia, Ciências e Letras de Ribeirão Preto/USP, Ribeirão Preto, SP, 14040-901, Brazil \\ ${ }^{\mathrm{c}}$ Faculdade de Engenharia de Ilha Solteira/UNESP, Ilha Solteira, SP, CP 31, 15385-000, Brazil \\ d Instituto Agronômico de Campinas/IAC, Campinas, SP, CP 28, 13012-970, Brazil
}

\section{A R T I C L E I N F O}

\section{Keywords:}

Hevea brasiliensis

Estimation of genetic parameters

Rubber yield

Multi-effect index

Selection gains

\begin{abstract}
A B S T R A C T
The objective of this work was to evaluate the genetic parameters and estimate genetic gains in two populations of Hevea brasiliensis. The first population of the study is originated from the primary forest of Rio Branco - Acre (wild population - PS), and the other population is originated from clonal matrices (improved population - PM). Thirty-seven progenies were evaluated at 23 years for PS. For PM, 31 progenies at eight years of age were evaluated for growth traits and dry rubber yield. Estimates of the genetic parameters were made using the univariate linear mixed-model additive model REML/BLUP and gains in selection by the Multi-Effects Index (MEI) method. The selection strategies of $50 \%, 40 \%$ and $22 \%$ of individuals for the character of dry rubber yield (PBS) and stem perimeter (PAP) using the multi-effects index revealed high and low selection gains in both populations. For MP, the strategy of selection between and within progenies was more appropriate and for PS, the individual selection. The gains obtained in the selection were $54 \%$ for the PBS character in the improved population of $0.46 \%$ for the PAP character for the wild population.
\end{abstract}

\section{Introduction}

The effectiveness of the rubber tree breeding program [Hevea brasiliensis (Willd. Ex Adr. de Juss.) Muell. - Arg.] depends on the availability of diversity in the germplasm collection. This diversity allows the obtainment of clones with high production potential, which are resistant to diseases, with products of better quality and adapted to adverse environmental conditions, among other attributes. The Amazon forest is the genetic diversity center of the rubber tree and it is being threatened by deforestation, which compromises the expansion of germplasm collections, mainly in terms of new attributes valued in rubber tree crop (Ambrósio et al., 2013).

In this context, in 1991 Engineering College at Ilha Solteira/UNESP, $\mathrm{SP}$, acquired seeds from open pollinating rubber trees originating from the primary forest of Rio Branco-Acre to settle a germplasm bank, which objective was to conserve the genotypes and, in the future, select them to establish an improvement program at the institution. Subsequently, in 2006, clonal test seeds were obtained from the Center of Rubber Tree and Agroforestry Systems, IAC (Agronomic Institute), with a certain degree of improvement, which would support the continuation of the breeding program.

The State of São Paulo has an improvement program, aimed at increasing production, associated with other desirable secondary characteristics, such as vigor, bark thickness and others (Aguiar et al., 2012). The vigor, measured by the stem perimeter, is the most important character to determine the clone precocity, allowing the rubber producer to have a faster financial return on their investment. The idea of the present study was to establish selection strategies aiming not only the production of latex, but also the quality of wood, guaranteeing to the producer the increment of income at the end of the crop cycle. Today, much of the wood of the rubber tree is destined for energy, adding low value to the product; the present study aimed to value the use of wood.

For the purpose of conducting an improvement program, knowledge of the genetic characteristics of study populations is essential to make selection more effective. Qualitative data are useful for estimating

\footnotetext{
* Corresponding author.

E-mail address: douradocl.cl@gmail.com (C.L. Dourado).
} 
genetic variation and based on heritability data and genetic correlations between economically important variables, genetic gains can be estimated after successive selection cycles. The quantitative data determine the most appropriate selection strategies to overcome the difficulties in the selection of superior genotypes and to increase knowledge about the genetic structure in populations of rubber trees (Silva et al., 2012).

One of the tools used in plant breeding programs are the mixed models, such as the Restricted Maximum Likelihood (REML), which is a generalization of Variance Analysis (ANOVA) for more complex situations and which allows the estimation of variance components and genetic parameters for the situation of unbalanced data and heterogeneity of variances. Another interesting procedure for the prediction of genetic values is the BLUP (Best Linear Unbiased Prediction), being more appropriate when considering the genotypic effects as random, aiming to obtain the BLUPs of said effects (Resende, 2004). The REML/ BLUP methodology is used in several species, such as in Hevea (Souza et al., 2017), Eucalyptus (Costa et al., 2015); Pinus (Santos et al., 2016), Acacia (black wattle) (Dunlop et al., 2005). Resende (2016) suggests the use of the Selegen-REML/BLUP software for the application of analysis of mixed models in the estimation of variance components and estimation of genetic parameters to optimize the conduction of plant breeding programs.

For Resende (1995), the adoption of efficient forest improvement strategies depends on the use of accurate selection methods. To do so, the Multi-Effects Index (IME) method can be used, which explores fractions of the additive genetic variance that are not considered in the selection between and within progenies and suggests that a more effective selection could be made by weighing individual values and values of their respective families. In this method, selection is based on genetic measures (net genetic value) and non-phenotypic measures of the candidates for selection (Resende and Higa, 1994). Several studies have been carried out using the MEI method, due to the more expressive gains in selection (Costa et al., 2000a, 2000b; Santos et al., 2016; Arantes et al., 2010; Tung et al., 2010; Silva et al., 2011; Verardi et al., 2013, 2014; Kubota et al., 2015).

Thus, the objective of the present study was to estimate the genetic parameters and gain prediction in selection for growth traits and rubber yield in two progenies of $\mathrm{H}$. brasiliensis. With this information, it was possible to verify the value of the genetic variation and the selection of the best selection strategy for the continuation of the breeding program of the species.

\section{Material and methods}

\subsection{Material}

The first population described by Paiva et al. (1994) is native to the primary forest of Rio Branco-Acre, generated by open pollination, characterized by not being submitted to any breeding program (PS, wild population) (Table 1). The second one is a population generated by open pollination of selected clonal matrices: 1-12-56-77, 64B 850, Fx (2261 and 3864), GT1, IAC (15, 35, 40, 41, 44, 301, 307 and 311), IAN 873, IRCA 111, MT 45, PB (28/59, 217, 235, 252, 260 and 330), Pind 595/89, PR (255 and 261), RO-I (35 and 110), RRIM (600, 606, 701 and 725), coming from the Center of Rubber Tree and Agroforestry Systems, IAC (Agronomic Institute). Therefore, it is part of an advanced stage improvement program (MP, improved population) (Table 2). The PS progeny test was installed on December 6, 1991, at a spacing of $5 \times 3 \mathrm{~m}$, with a randomized block design with 37 progenies distributed in three replications, unbalanced with a maximum of 10 plants per progeny. PM was installed as a progeny test on September 5, 2006, with a randomized complete block design, consisting of 31 treatments (progenies), four replications and linear plots of 10 plants, spaced $3 \times 3 \mathrm{~m}$.

The populations are installed as progeny tests at Teaching, Research and Extension Farm (FEPE)/Engineering College at Ilha Solteira/
Table 1

Wild population (PS) constituted by 37 progenies of open pollination situated in Selvíria, MS.

\begin{tabular}{|c|c|}
\hline Progenies & Size of the progenies \\
\hline 1 & 12 \\
\hline 2 & 13 \\
\hline 3 & 19 \\
\hline 4 & 19 \\
\hline 5 & 16 \\
\hline 6 & 25 \\
\hline 7 & 19 \\
\hline 8 & 13 \\
\hline 9 & 7 \\
\hline 10 & 11 \\
\hline 11 & 17 \\
\hline 12 & 14 \\
\hline 13 & 13 \\
\hline 14 & 12 \\
\hline 15 & 11 \\
\hline 16 & 21 \\
\hline 17 & 19 \\
\hline 18 & 14 \\
\hline 19 & 14 \\
\hline 20 & 3 \\
\hline 21 & 10 \\
\hline 22 & 9 \\
\hline 23 & 3 \\
\hline 24 & 6 \\
\hline 25 & 12 \\
\hline 26 & 9 \\
\hline 27 & 9 \\
\hline 28 & 12 \\
\hline 29 & 7 \\
\hline 30 & 10 \\
\hline 31 & 6 \\
\hline 32 & 8 \\
\hline 33 & 5 \\
\hline 34 & 3 \\
\hline 35 & 7 \\
\hline 36 & 6 \\
\hline 37 & 5 \\
\hline- & - \\
\hline
\end{tabular}

UNESP, located in Selvíria, MS. The approximate geographical location of the experiment area is at latitude $20^{\circ} 22^{\prime}$ ' $01^{\prime}$ ' S, longitude $51^{\circ} 25$ ' $08^{\prime}$ $\mathrm{W}$ and $357 \mathrm{~m}$ altitude. The relief is characterized as moderately flat and wavy. The climate of the site is Aw type, by Köppen classification, with an annual mean temperature of $24.5^{\circ} \mathrm{C}$, annual mean humidity of $64.8 \%$, average annual rainfall of $1232.2 \mathrm{~mm}$ and average sunshine of $7.3 \mathrm{~h} /$ day (Hernandez et al., 1995). The soil was classified as a Distroferric Red Latosol, clay texture (Embrapa, 2013).

\subsection{Methods}

\subsubsection{Evaluated characters}

The silvicultural characters were evaluated during 2 years (2014 and 2015), being them: a) Commercial height (AC) and total height (ALT) (m); b) stem perimeter at $50 \mathrm{~cm}$ above ground level (P50) (cm); c) Stem perimeter at $1,30 \mathrm{~m}$ above ground level (PAP) $(\mathrm{cm})$; d) Stem form (FOR), being this one obtained based on the arithmetic average between the two measures obtained by scale of marks from 1 to 5 (Kageyama et al., 1979), in which 1 mark (Trunk with very serious defect; very tortuous trunk), 2 marks (Trunk with severe defect; torso with tortuosity above average), 3 marks [Trunk with defect quite visible; torso with average tortuosity (up to $3,5 \mathrm{~m}$ in height)], 4 marks [Trunk with defect barely visible; trunk with tortuosity below average (up to $4,5 \mathrm{~m}$ in height)] and 5 marks attributed to the trunk with no blemish or trunk tending to righteousness $(>4,5 \mathrm{~m}$ in height). Obtained by the following expression: $\mathrm{FOR}=(\mathrm{BI}+\mathrm{TO}) / 2$, in which $\mathrm{BI}$ is the Bifurcation of the stem, with 1 mark (Bifurcation below 1,30 with diameter equal to the main stem), 2 marks (Bifurcation above 1,30 with 
Table 2

Improved population (PM) constituted by 31 progenies of open pollination located in Selvíria, MS.

\begin{tabular}{|c|c|c|}
\hline Order & Clone & Genealogy \\
\hline 1 & RRIM 600 ill. & RRIM 600 (Tjir 1 x PB 86) ill. \\
\hline 2 & IAC 40 ill. & IAC 40 [RRIM 608 (AVROS $33 \times$ Tjir 1) x AVROS 1279 (AVROS $156 \times$ AVROS 374)] ill. \\
\hline 3 & IAC 41 ill. & IAC 41 [RRIM 608 (AVROS 33 x Tjir 1) x AVROS 1279 (AVROS $256 \times$ AVROS 374)] ill. \\
\hline 4 & PB 235 ill. & PB 235 [PB 5/51 (PB 56 x PB24) x PB S/78 (PB 49 x PB 25)] ill. \\
\hline 5 & IAC 35 ill. & IAC 35 [(F $351 \times$ AVROS 49) x RRIM 600 (Tjir 1 x PB 86)] ill. \\
\hline 6 & 64 B 850 ill. & 64 B 850 [RRIM 623 (PB 49 x Pil B 84) x Fx 25 (F351 x AVROS 49)] ill. \\
\hline 7 & PB 260 ill. & PB 260 [PB 5/51 (PB 56 x PB 24) x PB49] ill. \\
\hline 8 & PB 252 ill. & PB 252 [РB 86 x PB 32/36 (PB 49 x PB 186)] ill. \\
\hline 9 & IRCA 111 ill. & IRCA 111 [PB 5/51(PB 56 x PB 24) x RRIM 600 (Tjir1 x PB 86)] ill. \\
\hline 10 & RRIM 606 ill. & RRIM 606 [Tjir 1 x PB 49] ill. \\
\hline 11 & RRIM 701 ill. & RRIM 701 [44/553 x RRIM 501 (Pil A 44 x Lun N)] ill. \\
\hline 12 & IAC 15 ill. & IAC 15 [RRIM 504 (Pil A 44 x Lun N) x RRIM 600 (Tjir 1 x PB 86)] ill. \\
\hline 13 & PB 28/59 ill. & PB 28/59 (PBIG seedling ill.) ill. \\
\hline 14 & IAC 311 ill. & IAC 311 [AVROS 509 (Pil A 44 x Lun N) x Fx 25 (F 351 x AVROS 49)] ill. \\
\hline 15 & IAC 301ill. & IAC 301 [RRIM 501 (Pil 49 X Lun N) x AVROS 1518 (AVROS 214 x AVROS 256)] ill. \\
\hline 16 & RO I 110 ill. & $\mathrm{RO} / \mathrm{I} / 110^{\mathrm{a}}$ ill. \\
\hline 17 & IAC 307 ill. & IAC 307 [AVROS 1328 (AVROS 214 x AVROS 374) x PR 107] ill. \\
\hline 18 & PR 255 ill. & PR 255 (Tjir 1 x PR 107) ill. \\
\hline 19 & RO I 35 ill. & $\mathrm{RO} / \mathrm{I} / 35^{\mathrm{a}}$ ill. \\
\hline 20 & IAN 873 ill. & IAN 873 (PB 85 x FA 1717) ill. \\
\hline 21 & IAC 44 ill. & IAC 44 [IAN 2325 [PB 86 x Fx 3933 (F 4542 x AVROS 363)] x AVROS 1328 (AVROS 214 x AVROS 374)] ill. \\
\hline 22 & PR 261 ill. & PR 261 (Tjir 1 x PR 107) ill. \\
\hline 23 & PB 217 ill. & PB 217 [РB 5/51 (РB 56 x PB 24) x PB 6/9] ill. \\
\hline 24 & GT1 ill. & GT1 ${ }^{\mathrm{a}}$ ill. \\
\hline 25 & PB 330 ill. & PB 330 [PB 5/51 (PB56 x PB 24) x PB 32/36 (PB 49 x PB 186)] ill. \\
\hline 26 & Fx 3864 ill. & Fx 3864 (PB 86 x FB 38) ill. \\
\hline 27 & MT/I/45 ill. & $\mathrm{MT} / \mathrm{I} / 45^{\mathrm{a}}$ ill. \\
\hline 28 & Fx 2261 ill. & Fx 2261 (F1619 x AVROS 183) ill. \\
\hline 29 & $1-12-56-77$ ill. & $1-12-56-77^{\mathrm{a}}$ ill. \\
\hline 30 & Pind 595/89 ill. & Pind 595/89 [RRIM 600 (Tjir 1 x PB 86)] ill. \\
\hline 31 & RRIM 725 ill. & Fx 25 ill. \\
\hline
\end{tabular}

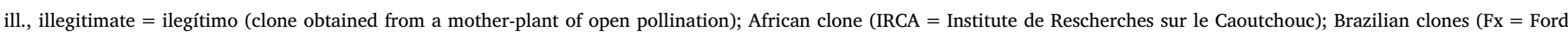

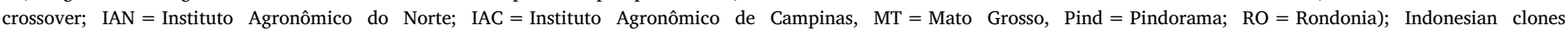

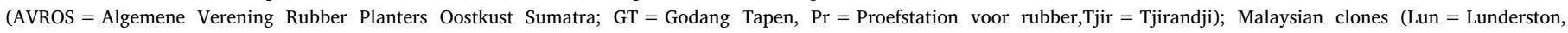
$\mathrm{PB}=$ Prang Besar, Pil = Pilmoor, RRIM = Rubber Research Institute of Malaysia); 1-12-56-77 (Malaysian clone).

${ }^{a}$ Primary clone deriving from unknown parentals obtained from the vegetative multiplication of the matrix tree with desirable characters.

diameter equal to the main stem), 3 marks (Bifurcation below 1,30 with a diameter that is inferior to the main stem), 4 marks (Bifurcation above 1,30 with diameter that is inferior to the main stem) and 5 marks being attributed to the absence of bifurcation. For the variable Righteousness, or the tortuosity of the stem (TO), it was evaluated in the experiment, with 1 mark (Tortuosity marked to the fullest extent), 2 marks (Tortuosity marked below $1,30 \mathrm{~m}$ ), 3 marks (Tortuosity marked above $1,30 \mathrm{~m}$ ), 4 marks (Slight tortuosity to the fullest extent) and 5 marks attributed to the trunk with no tortuosity; e) Mean diameter of the treetop projection (DMC), with projection of the treetop to the ground, on the line (DL) e in between line (DEL). The character (DMC) was generated by means of the arithmetic mean of the two measurements obtained, being presented by the following expression: $\mathrm{DMC}=(\mathrm{DL}+\mathrm{DEL}) / 2(\mathrm{~m}), \mathrm{f})$ Dry rubber yield was obtained by means of the Hamaker Morris-Mann test (HMM). In total, 15 consecutive tappings with the system of S/2 d7 ET 2,5\% (tapping in half-spiral every 7 days with stimulation of ethefon to $2.5 \%$ ) were performed. The first five consecutive tappings were discarded for panel stimulation (panel taming). Then, the ethephon was applied to $2.5 \%$, and 10 consecutive tappings were performed, which were duly quantified, obtaining the mass $(\mathrm{g})$ for each incision. For the two populations of the study, the five best trees were selected, by stem perimeter, from each progeny in three replicates. For the PM totaled 465 exploited trees. The PS was also selected with the same criterion, however, because there was not the same amount of trees per progeny, aggregating 190 trees exploited, because some progenies had less than five trees throughout the experiment.

\subsubsection{Statistical analysis}

The variance estimate components and genetic parameters were obtained by the method of maximum likelihood restricted and best linear unbiased prediction (REML/BLUP), using the statistic-genetic software SELEGEN-REML/BLUP (Resende, 2007b, 2016). The statistical model used was randomized blocks, progenies of half siblings, several plants per plot: $\mathbf{y}=\mathrm{Xr}+\mathrm{Za}+\mathrm{W} \mathbf{p}+\mathbf{e}$; in which: $\mathbf{y}, \mathbf{r}, \mathbf{a}, \mathbf{p}$ e e are vectors to data, repetition, parcels and errors. $\mathrm{X}, \mathrm{Z}$ e W are matrices of incidence (Resende, 2002; Resende, 2007a). Genetic and phenotypic parameters were estimated using the genetic statistical software Selegen - Reml/Blup (Model 93).

The individual heritability in narrow sense was estimated as: $\hat{h}_{a}^{2}=\hat{\sigma}_{a}^{2} / \hat{\sigma}_{f}^{2}$; in which $\hat{\sigma}_{a}^{2}$ is the additive genetic variance and $\hat{\sigma}_{f}^{2}$ is the individual phenotypic variance, in which $\left(\hat{\sigma}_{f}^{2}=\hat{\sigma}_{a}^{2}+\hat{\sigma}_{c}^{2}+\hat{\sigma}_{e}^{2}\right)$, in which $\hat{\sigma}_{c}^{2}$ (environmental variance among plots) and $\hat{\sigma}_{e}^{2}$ is the residual variance (environmental + non additive).

Individual heritability in narrow sense, adjusted to the plots effects, as $\hat{h}_{a j}^{2}=\hat{\sigma}_{a}^{2} / \hat{\sigma}_{a}^{2}+\hat{\sigma}_{e}^{2}$; the coefficient of determination of plot effects was estimated as: $\hat{C}_{p}^{2}=\hat{\sigma}_{c}^{2} / \hat{\sigma}_{f}^{2}$.

Mean heritability of progenies, was estimated as: $\hat{h}_{m}^{2}=(1 / 4) \hat{\sigma}_{a}^{2} /(1 / 4) \hat{\sigma}_{a}^{2}+\left(\hat{\sigma}_{c}^{2} / r\right)+\left(0,75 \hat{\sigma}_{a}^{2}+\hat{\sigma}_{e}^{2}\right) / n r$, in which: $n$ : number of plants per plots and $r$ the number of repetitions. Accuracy of the selection of progenies, was estimated as: $\hat{r}_{\hat{a} a}=\sqrt{\hat{h}_{m}^{2}}$. Additive heritability within plots, as: $\hat{h}_{a d}^{2}=0,75 \hat{\sigma}_{a}^{2} / 0,75 \hat{\sigma}_{a}^{2}+\hat{\sigma}_{e}^{2}$.

The coefficient of individual additive genetic variation, as: $C V_{g i}(\%)=\left(\sqrt{\hat{\sigma}_{a}^{2}} / \hat{m}\right) 100$.Coefficient of genotypic variation among progenies, as: $C V_{g p}(\%)=\left(\sqrt{0,25 \hat{\sigma}_{a}^{2}} / \hat{m}\right) 100$.The experimental variation coefficient, as: $C V_{e}(\%)=\left(\sqrt{\left[\left(0,75 \hat{\sigma}_{a}^{2}+\hat{\sigma}_{e}^{2}\right) / n\right]+\hat{\sigma}_{c}^{2}} / \hat{m}\right) 100$, in which $\hat{m}$ as overall mean of the experiment and coefficient of relative variation, as: $C V_{r}=C V_{g p} / C V_{e}$ 


\subsubsection{Selection by the multi-effects index (MEI) method}

To estimate the gain of selection, two simulations of strategies were used. First simulation, the selection of the first individuals that presented the highest estimates of $\hat{a}$, not taking into account the number of individuals that each progeny could have $\left(k_{f}=\forall\right)$, that is, $k_{f}$ with any value, since $k \neq 0$. For each population, the intensity of 50\% individual resulting in the total number of individuals selected, variable between the two populations. Second simulation, the selection establishing a limit value of $k_{f}$, in this case, the $k_{f}$ considered was equal to the number of 12 trees per family, which represented intensity of selection of $40 \%$ for PM and of $22 \%$ for PS. The character used in the selection was the one with the highest value of the relative coefficient of variation $\left(C V_{r}\right)$ obtained for each one of the populations studied.

The IME was used to estimate the gains in the selection using the expression (Resende, 2002): $\quad \hat{I}=\hat{b}_{1} Y_{i j k}+\left(\hat{b}_{2}-\hat{b}_{3}\right) \cdot \bar{Y}_{i . .}+$ $\left(\hat{b}_{3}-\hat{b}_{1}\right) \bar{Y}_{i j .}-\hat{b}_{3} \bar{Y}_{j .}+\left(\hat{b}_{3}-\hat{b}_{2}\right) \cdot \bar{Y}_{\ldots}$, in which, $\hat{I}$ : index multi-effects; $\bar{Y}_{\ldots}$ : overall mean of the test; $\mathrm{Y}_{\mathrm{ijk}}$ : individual value; $\overline{\mathrm{Y}}_{i . .}$ : mean of the progeny on the test; $\bar{Y}_{i j}$ : mean of the progeny in a certain block (mean of the plot); $\overline{\mathrm{Y}}_{\mathrm{j} . \mathrm{l}}$ : mean of the block; $\hat{\mathrm{b}}_{1}=\hat{\mathrm{h}}_{\mathrm{d}}^{2}$ (heritability, in narrow sense, within plots); $\hat{b}_{2}=\hat{\mathrm{h}}_{\mathrm{m}}^{2}$ (heritability, in narrow sense among mean of progeny); $\hat{b}_{3}=\hat{h}_{p}^{2}$ (heritability, in narrow sense, of plots). The effective population size $\left(\mathrm{N}_{\mathrm{e}}\right)$ was obtained based on Resende (2002): $N_{e}=\left(4 N_{f} \bar{k}_{f}\right) /\left[\bar{k}_{f}+3+\left(\sigma_{k f}^{2} / \bar{k}_{f}\right)\right]$, in which: $\bar{k}_{f}=$ average number of individuals selected by matrix; $\sigma_{\mathrm{kf}}^{2}=$ variance of the number of individuals selected by matrix; $N_{f}=$ number of matrices selected. The genetic diversity $(D)$, after the selection, was quantified according to Wei and Lindgren (1996), $D=N_{e f} / N_{f o}$, in which $0<D \leq 1$; $N_{f o}=$ original number of matrices; $N_{e f}=$ effective number of matrices selected, being that given by: $N_{e f}=\left(\sum k_{f}\right)^{2} / \sum k_{f}{ }^{2}$. The value was generated by the following expression: $\left.G s(\%)=\left[\left(\sum \hat{a}\right) /\left(\sum k_{f}\right) 100\right)\right] / \hat{m}$ ; in which, $\hat{a}$ corresponds to the multi effects index $(\hat{I})$ and $\hat{m}$ the overall mean of the character.

\section{Results and discussion}

\subsection{Estimates of genetic parameters}

According to the likelihood ratio test (LRT) obtained by the deviance analysis, for PM the significant characters were: DMC, P50, PAP and PBS (Table 3). For PS, the significant characters were: ALT, DMC, P50 and PAP (Table 4). This information is very important because for genetic progress to be made through selection it is necessary to have variance between progenies (Freitas et al., 2009). It suggests that the selection of individuals can be performed using one of these characters, showing real differences and not for random reasons in families. For both populations, the FOR character did not present any significance, indicating that the families present a more uniform straightness and bifurcation of the stem, and therefore, it is not an exclusive and potential character of these families. For PM, measured at age eight, neither the height nor the commercial height were significant, probably because they did not reach their full potential for vertical growth, as occurs in PS, measured at age 23 years. However, since the PM presents a certain degree of genetic improvement, the PBS character presented significance, unlike the PS, that comes from a natural population of free feet.

The experimental variation coefficient $\left(C V_{e}\right)$ presented values considered as high magnitude for PBS, according to Pimentel-Gomes and Garcia (2002). These values are similar to the ones found by Costa et al. (2000a, 2000b) and Souza et al. (2017), being considered as common the high values of $C V_{e}$ for this character since the collection of this one is subjected to experimental errors of control relatively difficult and expresses intrinsic properties of the character. However, the accuracy $\left(\hat{r}_{\hat{a} a}\right)$ which indicates accuracy in access to true genetic variation from phenotypic variation, in the present study presented as "high" (70\% to $85 \%)$ and "moderate" (50\% to 65\%) according to the classification by Resende and Duarte (2002). According to Resende (2002), accuracy is a measure that is associated with precision in selection, being the main component of genetic progress, therefore, the values found in the present study suggest a greater reliability in the estimates.

The mean values obtained for PAP and P50 for PM were 46 and $60 \mathrm{~cm}$ indicating a sufficient perimeter for panel opening $(45-50 \mathrm{~cm})$ (Pereira and Pereira, 2001; Gonçalves, 2007). Even though these values may be few expressive, for the age of eight, due to the panel opening to be carried out with seven years in commercial plantations, there are still, at present, earlier clones that present this minimum perimeter for panel opening between six and five years for PM. However, for PS, these values were 76 and $94 \mathrm{~cm}$, respectively, more expressive values, fact evidenced due to the 15 years difference between the experiments, with eight and 23 years after implantation, respectively.

The averages of total height were 15.39 and $18.71 \mathrm{~m}$ for PM and PS respectively, corresponding to an average annual increment of 1.9 and $0.81 \mathrm{~m}$. These values are high because, for the species between 7 and $10 \mathrm{~m}$, it is considered a medium height, and very large, reaching

Table 3

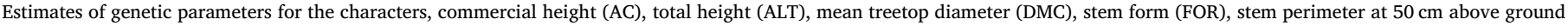
level (P50), stem perimeter at $1.30 \mathrm{~m}$ above ground level (PAP) and dry rubber yield (PBS), in rubber tree progenies, improved population (PM) at eight years, in Selvíria, MS.

\begin{tabular}{|c|c|c|c|c|c|c|c|}
\hline Estimates & $\mathrm{AC}(\mathrm{m})$ & ALT (m) & $\mathrm{DMC}(\mathrm{m})$ & FOR & P50 (cm) & $\mathrm{PAP}(\mathrm{cm})$ & PBS (g) \\
\hline$\hat{h}_{a}^{2}$ & $0.08 \pm 0.05$ & $0.15 \pm 0.07$ & $0.25 \pm 0.09$ & $0.06 \pm 0.04$ & $0.31 \pm 0.10$ & $0.25 \pm 0.09$ & $0.66 \pm 0.21$ \\
\hline$\hat{h}_{a j}^{2}$ & 0.09 & 0.18 & 0.26 & 0.06 & 0.31 & 0.25 & 0.68 \\
\hline$\hat{C}_{p}^{2}$ & 0.1210 & 0.1614 & 0.0090 & 0.0208 & 0.0026 & 0.0025 & 0.0328 \\
\hline$\hat{h}_{m}^{2}$ & 0.28 & 0.39 & 0.71 & 0.32 & 0.77 & 0.72 & 0.85 \\
\hline$\hat{r}_{\hat{a} a}$ & 0.53 & 0.62 & 0.85 & 0.57 & 0.88 & 0.85 & 0.92 \\
\hline$\hat{h}_{a d}^{2}$ & 0.07 & 0.14 & 0.21 & 0.04 & 0.26 & 0.20 & 0.62 \\
\hline$C V_{g i}(\%)$ & 14.59 & 7.10 & 12.41 & 4.99 & 14.27 & 13.48 & 88.32 \\
\hline$C V_{g p}(\%)$ & 7.29 & 3.55 & 6.20 & 2.50 & 7.14 & 6.74 & 44.16 \\
\hline$C V_{e}(\%)$ & 23.12 & 8.95 & 7.85 & 7.23 & 7.84 & 8.36 & 36.53 \\
\hline$C V_{r}$ & 0.32 & 0.40 & 0.79 & 0.34 & 0.91 & 0.81 & 1.21 \\
\hline$\hat{m}$ & 7.57 & 15.39 & 4.75 & 3.71 & 59.88 & 46.12 & 246.73 \\
\hline LRT $\left(\chi^{2}\right)$ & $1.15^{\mathrm{ns}}$ & $2.63^{\text {ns }}$ & $15.86^{\mathrm{a}}$ & $1.34^{\mathrm{ns}}$ & $28.25^{\mathrm{a}}$ & $22.32^{\mathrm{a}}$ & $16.94^{\mathrm{a}}$ \\
\hline
\end{tabular}

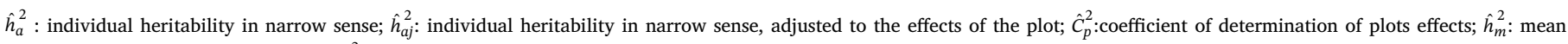

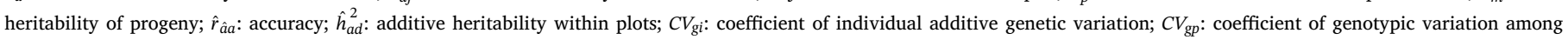
progenies; $C V_{e}$ : coefficient variation experimental; $C V_{r}$ : coefficient of residual variation; $\hat{m}$ : overall means.

${ }^{\mathrm{a}}\left(\chi^{2}\right)$ significant in $1 \%(6,63)$.

ns not significant. 
Table 4

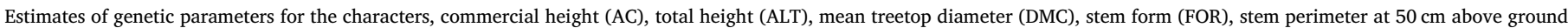
level (P50), stem perimeter at $1.30 \mathrm{~m}$ above ground level (PAP) and dry rubber yield (PBS), in rubber tree progenies, wild population (PS) at age 23 in Selvíria, MS.

\begin{tabular}{|c|c|c|c|c|c|c|c|}
\hline Estimates & $\mathrm{AC}(\mathrm{m})$ & $\operatorname{ALT}(\mathrm{m})$ & $\mathrm{DMC}(\mathrm{m})$ & FOR & P50 $(\mathrm{cm})$ & $\mathrm{PAP}(\mathrm{cm})$ & PBS (g) \\
\hline$\hat{h}_{a}^{2}$ & $0.20 \pm 0.12$ & $0.43 \pm 0.18$ & $0.47 \pm 0.19$ & $0.26 \pm 0.14$ & $0.39 \pm 0.17$ & $0.60 \pm 0.21$ & $0.39 \pm 0.27$ \\
\hline$\hat{h}_{a j}^{2}$ & 0.20 & 0.49 & 0.50 & 0.27 & 0.42 & 0.66 & 0.54 \\
\hline$\hat{C}_{p}^{2}$ & 0.0059 & 0.1293 & 0.0731 & 0.0363 & 0.0614 & 0.0807 & 0.2845 \\
\hline$\hat{h}_{m}^{2}$ & 0.60 & 0.61 & 0.69 & 0.60 & 0.67 & 0.74 & 0.46 \\
\hline$\hat{r}_{\hat{a} a}$ & 0.77 & 0.78 & 0.83 & 0.78 & 0.82 & 0.86 & 0.68 \\
\hline$\hat{h}_{a d}^{2}$ & 0.15 & 0.42 & 0.43 & 0.21 & 0.35 & 0.59 & 0.47 \\
\hline$C V_{g i}(\%)$ & 24.93 & 13.09 & 21.27 & 7.69 & 18.22 & 26.48 & 47.25 \\
\hline$C V_{g p}(\%)$ & 12.46 & 6.54 & 10.64 & 3.85 & 9.11 & 13.24 & 23.63 \\
\hline$C V_{e}(\%)$ & 17.88 & 9.05 & 12.23 & 5.39 & 11.06 & 13.52 & 44.71 \\
\hline$C V_{r}$ & 0.70 & 0.72 & 0.87 & 0.71 & 0.82 & 0.98 & 0.53 \\
\hline$\hat{m}$ & 7.46 & 18.71 & 5.94 & 3.99 & 94.43 & 76.73 & 282.40 \\
\hline $\operatorname{LRT}\left(\chi^{2}\right)$ & $3.22^{\text {ns }}$ & $4.83^{\mathrm{a}}$ & $6.81^{\mathrm{b}}$ & $2.97^{\mathrm{ns}}$ & $5.54^{\mathrm{a}}$ & $10.64^{\mathrm{b}}$ & $0.89^{\mathrm{ns}}$ \\
\hline
\end{tabular}

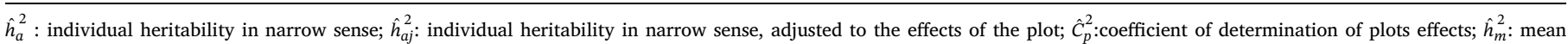

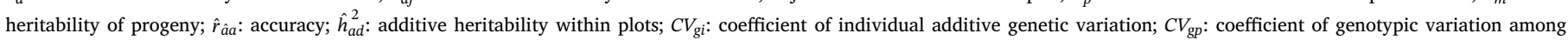
progenies; $C V_{e}$ : coefficient variation experimental; $C V_{r}$ : coefficient of residual variation; $\hat{m}$ : overall means.

${ }^{\mathrm{a}}\left(\chi^{2}\right)$ significant in $5 \%(3,84)$.

b $\left(\chi^{2}\right)$ significant in $1 \%(6,63)$.

ns not significant.

15-50 $\mathrm{m}$ in height, mainly for the population improved being only 8 years old, being considered, therefore, on average large trees. Commercial heights were the same for both populations reaching $7.5 \mathrm{~m}$, showing the potential for future timber (PM) exploration, which has already reached the same commercial height as the 23-year-old population, although the wild population is spacing of $5 \times 3 \mathrm{~m}$, allowing greater crown branching. A similar feature that may justify higher values obtained with DMC for PS ( $5.9 \mathrm{~m}$ ) versus $4.8 \mathrm{~m}$ for PM, despite the age difference, spacing may also have contributed to higher horizontal growth treetop.

For the FOR character, the two populations presented average values close to 4 , in the scale of notes, indicating in general, slight tortuosity in all extension of the stem, presenting great characteristic for future explorations of the wood.

For the PBS character, the mean was $246 \mathrm{~g}$ for PM and slightly higher for PS with $282 \mathrm{~g}$, but considering the number of plants explored, PBS was $53 \mathrm{~g} \mathrm{plant}^{-1}$ for the improved population, and $148 \mathrm{~g}$ plant $^{-1}$ for the wild population, even with a smaller number of exploited plants, and despite the improved feature, the upper perimeter contributed to higher production. Arantes et al. (2010), found a superior average of $94,73 \mathrm{~g} \mathrm{plant}^{-1}$, at 3 years old for the same progenies of the improved population, despite exploiting fewer trees in comparison to the present study.

The coefficient of individual additive genetic variation $\left(C V_{g i}\right)$, which expresses in percentage of overall average the existent quantity of genetic variation, presented high magnitude for the PBS character in relation to the other characters evaluated, for the two populations ( $47 \%$ and $88 \%$ ), a situation that is similar to the other studies (Costa et al., 2000a; Costa et al., 2008; Arantes et al., 2010). The coefficient of genetic variation for PM was significantly higher than the others for this character, with $88 \%$, indicating the improved nature of the population, for this character. Other characters that stood out, but with smaller magnitude, were AC, DMC, P50 and PAP with amplitude of $12-15 \%$, for the PM, and for all the characters of the PS, with amplitude of 13-25\% with the exception of the character FOR. The wild population presented values of $C V_{g i}$ with magnitudes higher than the PM, due to the fact that the age of 23 contributes with mean values of height, and more expressive treetop and perimeters. According to Aguiar et al. (2010), the bigger the value for the $C V_{g i}$, the easier it will be to find superior individuals that will be able to provide gains in the selection. In this context, on average between the two populations, the characters that have the highest values of this coefficient are PAP and PBS, suggesting the use of this parameter for selection. The values of the genotype coefficient of variation between progenies $\left(C V_{g p}\right)$ were of lower magnitude for PM, than for PS, in general from low to medium magnitudes, however, the $C V_{g p}$ for the PBS character was of high magnitude for the improved population with $44 \%$. The heritability corresponds to the relative proportion of genetic and environmental influences on phenotypic expression and indicates ease or difficulty in improving certain traits (Souza et al., 2017). Resende (1995) classifies heritability values ranging from 0.01 to 0.15 as low, from 0.15 to 0.50 medians and above 0.50 as high. The values of the mean heritability of progenies $\left(\hat{h}_{m}^{2}\right)$ were shown from medians to high magnitudes (28-85\%). In general, PS presented high values for almost all the characters (60-74\%), except for PBS with a moderate value of $46 \%$. The expressive values of heritability of progeny averages for all the traits studied indicate that the selection can be more effective using the information of the families.

The additive heritability within plot $\left(\hat{h}_{a d}^{2}\right)$ for the improved population presented values from low to high ( 4 to $62 \%$ ) and for the wild population presented from mean to high magnitudes (15-59\%). The individuals heritabilities in the narrow sense, adjusted for the purpose of plot $\left(\hat{h}_{a j}^{2}\right)$ presented similar situations as to the ones that occurred with $\hat{h}_{a d}^{2}$.

The individual heritability $\left(\hat{h}_{a}^{2}\right)$ that quantifies the relative importance of the genetic additive proportion that can be transmitted to the next generation presented mean values at high magnitudes (25 to $66 \%$ ) for the two populations. Only AC and FOR presented inferior $\hat{h}_{a}^{2}$, with low magnitudes (8 and 6\% respectively), para a PM. According to Souza et al. (2017), it is common to note differences among the $\hat{h}_{a}^{2}$, since the characters evaluated have a quantitative inheritance, that is, they are influenced by the environment. In comparison to the values of $\hat{h}_{m}^{2}$, according to Resende (2002), it is expected to find, for quantitative characters, values of low magnitude for the individual heritability and that, in general, one conduces the estimate of magnitude from moderate to high for the heritability at the average progeny level.

In general, PS had heritability of larger magnitudes than PM. The characters that presented the greatest magnitude for the heritability were PBS for improved population and PAP and PBS for the wild population. For the three types of heritability, some authors obtained similar results for PBS characters with a perimeter of more than $60 \%$ (Gonçalves et al., 2005; Costa et al., 2008; Costa et al., 2010; Verardi 
et al., 2011; Verardi et al., 2014).

The values of the coefficient of relative variation $\left(C V_{r}\right)$ were higher than 0,45 for all the characters that were evaluated in PS and for the characters DMC, P50, PAP e PBS, para a PM. According to Vencosvsky and Barriga (1992), the higher the value of the $C V_{r}$ (high magnitude), the greater the genetic control of the characters and the lower the influence by environmental factors, therefore, characters, commonly chosen, with better perspectives, for obtaining expressive gains in the selection. In this work, the characters with higher magnitude of $C V_{r}$ it was PBS (1.21) and PAP (0.98) for PM and PS respectively, that served as object of selection by the multi-effect index in the next item of study.

The experimental design was favorable, as the environmental heterogeneity did not prevail within blocks, with the coefficient of determination of plot effects $\left(\hat{C}_{p}^{2}\right)$ with low magnitudes $(0.2-8 \%)$. Some characters presented $\hat{C}_{p}^{2}$ a little higher, that is due to larger values of residual variation, as for the characters ALT (16\%), AC (12\%) for the improved population and ALT (13\%), PBS (28\%) for the wild population. According to Sturion and Resende (2010), values greater than $10 \%$ indicate that there was environmental heterogeneity within the plots. It is recommended, in this case, the decrease of the number of plants per plot and the increase of the blocks. Thus, modifying the arrangement of the experimental design could minimize the errors, consequently reducing the value of the $\hat{C}_{p}^{2}$.

\subsection{Prediction of selection gains}

There are studies that show that vigor (measured by stem perimeter) is considered the most important character to determine the precocity of the clone, allowing the rubber tree producer to have a faster return of its investment, with greater production in the first years of life, which confirm the efficiency of the early tests (Alem et al., 2015). Based on the high correlation between annual perimeter growth and rubber production and observed results, it is possible to predict that selection with this population is possible in young plants with maximum gain and in short time, minimizing the rubber production cycle (Gonçalves et al., 2006; Verardi et al., 2014). Thus, these two characters were chosen for the use of selection strategies employing the Multi-Effects Index (MEI). The selection intensity among progenies was 50\% for the best individuals, based on the classification by the BLUPs, in descending order, in the SELEGEN software analysis, for the two study populations, resulting in 233 individuals for PM and 408 for PS. For PM, the intensity of $40 \%$ was used within families, and for PS the intensity was $22 \%$, representing, for both populations, 12 individuals per family (Table 5).

When it comes to the improved population, according to the strategy applied selecting the 233 best individuals and with a fixed $k_{f}$ of 12 plants per progeny made a $\hat{G}_{s}$ of $51 \%$ and $54 \%$ possible, for the first and the second strategy, respectively. These values fell short of those found by Arantes et al. (2010) who obtained superior gains in the

Table 5

Selection by the Multi-Effects Index (MEI), for the character of dry rubber yield (PBS, g) in $\mathrm{PM}$ and for stem perimeter (PAP, $\mathrm{cm}$ ) in PS, for Hevea brasiliensis in Selvíria, MS.

\begin{tabular}{llllll}
\hline Parameters & \multicolumn{2}{l}{ PM (PBS) } & & & \multicolumn{2}{l}{ PS (PAP) } \\
\cline { 2 - 3 } \cline { 5 - 6 } & $k_{f}=\forall$ & $k_{f}=12$ & & $k_{f}=\forall$ & $k_{f}=12$ \\
\hline$N$ & 233 & 372 & & 408 & 444 \\
$N_{f o}$ & 31 & 31 & & 37 & 37 \\
$N_{e}$ & 69.53 & 99.20 & & 98.59 & 118.4 \\
$\hat{\sigma}_{k f}^{2}$ & 19.03 & 0 & & 27,86 & 0 \\
$\hat{G}_{S}(\%)$ & 51.16 & 54.19 & & 0.46 & 3.68 \\
$\hat{D}$ & 0.73 & 1.00 & & 0.82 & 1
\end{tabular}

$N$ : number of individuals selected; $N_{f o}=$ number of progenies of the original population; $N_{e}$ : populational effective size; $\hat{\sigma}_{k f}^{2}$ : variance of individuals selected per progeny; $\hat{G}_{s}$ : gains in the selection; $\hat{D}$ : Genetic diversity. selection with the same population of $68 \%$. Verardi et al. (2014), comparing several selection methods, found superiority by MEI, with gains over $100 \%$ for dry rubber yield, in all the years studied, for rubber trees.

The effective population size $N_{e}$, corresponded from 69 to 99 for the individual selection and among and inside families, respectively. The selection between and within proved to be favorable in relation to the individual selection, since it guarantees diversity in 100\%, keeping all families in the selection, since for individual selection two families are lost (RO-I 35, Pind 595/89). Moreover, the applied intensity of selection is smaller in the selection among and within the study of $40 \%$. The use of high intensities of selection is a risky strategy in a breeding program. A selection of intense individuals for a high heritability character should be treated cautiously, as this practice may lead to the elimination or early loss of alleles responsible for other characters (Kageyama and Vencovsky, 1983), loss of favorable alleles may occur due to genetic drift associated with selective processes (Pereira and Vencovsky, 1988). Reduction in effective population size may lead to inbreeding and loss of vigor (Oda et al., 1989). In the present situation, the PM had greater selection gains in comparison to the PS, but a greater intensity of selection was applied, and with this greater loss in diversity could occur the loss of favorable alleles in this population as previously mentioned, in this way it is recommended to choose the second selection method, with $k_{f}$ equal to 12 .

The genetic diversity for the populations after the first selection presented expressive values of 0.73 and 0.82 for PM and PS, respectively. Although the PS has a greater genetic diversity, the PM also presented an expressive value, although the matrices are of a clonal nature, there is still great genetic variability among the progenies.

For PS, there were less significant selection gains from $\left(\hat{G}_{s}=0,46 \%\right.$ to $3,68 \%$ ). However, this strategy retained a larger effective population size $N_{e}$, for the wild population, varying from 98 to 118 from one selection to another, than in the case of PM (69-99). However, considering the situation of lack of uniformity of the wild population, the individual selection would be the most realistic to be adopted a priori. The selection strategy adopted for this population was consistent with the statement by Moraes (2001), who mentions the selection of the best individuals by the MEI, delimiting the maximum value of individuals selected by progeny $(k f)$, an increase in the number of progenies, maintain adequate population size and retain genetic diversity.

For the wild population only a simulation was performed, for predictions for possible future access of the genetic material, as seed orchard formations, in the use of the breeding. Since the population is free-footed, native to Acre, that is, having a great importance for germplasm bank and ex situ conservation. They have a 55\% survival rate. Thus, it was intentional to apply $50 \%$ intensity in the selection so that the maximum of possible individuals could be found. Even so, it was possible to obtain a discreet gain in the selection.

According to Resende and Fernandes (1999), the Multi-Effects Index method is an optimal selection procedure, equivalent to the BLUP procedure (best unbiased linear prediction) for the case where the data is balanced, or survival is greater than $85 \%$. What can present in part, smaller gains in the selection for PS, because they present $55 \%$ of survival. Therefore, the strategy initially adopted was intentional, aiming at the conservation of the genetic material.

Kageyama et al. (2002) found average predicted gains surprising for natural populations of $H$. brasiliensis, in Acre, for dry rubber production, with selection by individual genetic values of $66 \%$. These are important predictions because, according to the same authors, there is a low production of latex in the native rubber trees of Acre resulting from the heterogeneity of the trees, since a few produce a high amount of latex and the great majority produces little, promoting a low yield. That is why there is a need for clones, which, in turn, are more susceptible to M. ulei.

Several selection methods can be used, it is up to the breeder to check which ones meet their short, medium and long term demands. 
Improvement methods can also be used for each one of the stages of an improvement program, such as increasing the intensity of selection, obtaining greater gains in the short term or decreasing the intensity of selection in order to guarantee the gains over time (Costa et al., 2016).

\section{Conclusions}

The estimated genetic parameters between growth traits and dry rubber production for the two rubber populations indicate a favorable selection situation, contributing to promising genetic advances in the breeding program.

The MEI-based selection provided promising selection gains without drastically affecting effective size and diversity in rubber populations, with the most appropriate strategy being selection within progenies, providing adequate levels of genetic variability and possible seed orchard formation.

\section{Acknowledgments}

The authors would like to thank the Fundação de Amparo à Pesquisa from the state of São Paulo (FAPESP) and the Conselho Nacional de Desenvolvimento Científico e Tecnológico (CNPq) for funding the research.

\section{References}

Aguiar, A.V., Sousa, V.A., Shimizu, J.Y., 2010. Seleção genética de progênies de Pinus greggii para formação de pomares de sementes. Pesquisa Florestal Brasileira 30, 107-117.

Aguiar, A.T.E., Brancalião, S.R., Rossi, C.E., 2012. Avaliação do desempenho inicial de progênies de seringueira. Nucleus 9 (1), 115-122.

Alem, H.M., Gouvêa, L.R.L., Silva, G.A.P., Oliveira, A.L.B., Gonçalves, P.S., 2015. Avaliação de clones de seringueira para a região noroeste do Estado de São Paulo. Ceres 62 (5), 430-437.

Ambrósio, L.A., Gonçalves, E.C.P., Martins, A.L.M., 2013. Dinâmica da Coleção de Germoplasma de Seringueira: modelo computacional. Boletim de Dinámica de Sistemas 34, 1-12.

Arantes, F.C., Gonçalves, P.S., Scaloppi Junior, E.J., Moraes, M.L.T., Resende, M.D.V., 2010. Ganho gençtico com base no tamanho efetivo populacional de progénies de seringueira. Pesquisa Agropecuêria Brasileira 45 (12), 1419-1424.

Costa, R.B., Resende, M.D.V., Araujo, A.J., Gonçalves, P.S., Higa, A.R., 2000a. Selection and genetic gain in rubber tree (Hevea) populations using a mixed mating system. Genet. Mol. Biol. 23 (3), 671-679.

Costa, R.B., Resende, M.D.V., Araujo, A.J., Gonçalves, P.S., Silva, M.A., 2000b. Maximization of genetic gain in rubber tree (Hevea) breeding with effective size restriction. Genet. Mol. Biol. 23 (2), 457-462.

Costa, R.B., Resende, M.D.V., Gonçalves, P.S., Oliveira, L.C.S., Ítavo, L.C.V., Roa, R.A.R., 2008. Seleção simultânea para porte reduzido e alta produção de látex em seringueira. Bragantia 67 (3), 649-654.

Costa, R.B., Resende, M.D.V., Gonçalves, P.S., Roa, R.A.R., Feitosa, K.C.O., 2010. Predição de parâmetros e valores genéticos para caracteres de crescimento e produção de látex em progênies de seringueira. Bragantia 69 (1), 49-56.

Costa, R.B., Martinez, D.T., Silva, J.C., Almeida, B.C., 2015. Variability and genetic gains in Eucalyptus camaldulensis progenies using different selection methods. Revista de Ciências Agrárias 58, 69-74. http://dx.doi.org/10.4322/rca.1668.

Costa, R.M.L., Estopa, R.A., Biernaski, F.A., Mori, E.S., 2016. Predição de ganhos genéticos em progênies de Eucalyptus benthamii Maiden \& Cambage por diferentes métodos de seleção. Scientia Forestalis 44 (109), 105-113.

Dunlop, R.W., Resende, M.D.V., Beck, S.L., 2005. Early assessment of first year height data from Five Acacia mearnsii (black wattle) sub-populations in South Africa using REML/BLUP. Silvae Genetica 54, 166-174.

Empresa Brasileira de Pesquisa Agropecuária- Embrapa, 2013. Sistema brasileiro de classificação dos solos, 3rd ed. Embrapa, Brasília (353 p.).

Freitas, R.G., Vasconcelos, E.S., Cruz, C.D., Rosado, A.M., Rocha, R.B., Takami, L.K. 2009. Predição de ganhos genéticos em progênies de polinização aberta de Eucalyptus urograndis cultivadas em diferentes ambientes e submetidas a diferentes procedimentos de seleção. Revista Árvore 33 (2), 25-263.

Gonçalves, P.S., 2007. Melhoramento genético da seringueira: métodos formais e moleculares. Informe Agropecuário 28 (237), 95-104.

Gonçalves, P.S., Bortolleto, N., Cardinal, A.B.B., Gouvêa, L.R.L., Costa, R.B., Moraes, M.L.T., 2005. Age-age correlation for early selection of rubber tree genotypes in São Paulo, Brazil. Genet. Mol. Biol. 28 (4), 758-764.

Gonçalves, P.S., Silva, M.A., Gouvêa, L.R.L., Scaloppi Junior, E.J., 2006. Genetic variability for girth growth and rubber yield in Hevea brasiliensis. Scientia Agricola 63 (3), 246-254.
Hernandez, F.B.T., Lemos Filho, M.A.F., Buzetti, S., 1995. Software HIDRISA e o balanço hídrico de Ilha Solteira. Faculdade de Engenharia de Ilha Solteira, Universidade Estadual Paulista, Ilha Solteira 45 p. (Série Irrigação, 1).

Kageyama, P.Y., Vencovsky, R., 1983. Variação genética em progênies de uma população de Eucalyptus grandis (Hill) Maiden. IPEF 24, 9-26.

Kageyama, P.Y., Krugner, T.L., Mora, A.L., Bertoloti, G., Gaiad, S., 1979. Avaliação de progênies de árvores superiores de Eucalyptus grandis (nota prévia). IPEF, Piracicaba 9 p.

Kageyama, P.Y., Oliveira, R.S., Ferraz, P.A., Furtado, E.L., Souza, A.D., Sebbenn, A.M., 2002. Ganhos na seleção para a produtividade de látex em população natural de Hevea brasiliensis na Reserva Chico Mendes: estudo de caso das IAPs (Ilhas de alta produtividade). Scientia Forestalis 61, 79-85.

Kubota, T.Y.K., Moraes, M.A., Silva, E.C.B., Pupin, S., Aquiar, A.V., Moraes, M.L.T., Freitas, M.L.M., Sato, A.S., Machado, J.A.R., Sebbenn, A.M., 2015. Variabilidade genética para caracteres silviculturais em progênies de polinização aberta de Balfourodendron riedelianum (Engler). Scientia Forestalis 43 (106), 407-415.

Moraes, M.L.T., 2001. Variação genética e aplicação da análise multivariada em progênies de Pinus caribaea var. hondurensis Barret e Golfari. Faculdade de Engenharia. Universidade Estadual Paulista, Ilha Solteira 124 p. Tese (Livre Docência).

Oda, S., Menck, A.L.M., Vencovsky, R., 1989. Problemas no melhoramento genético clássico do Eucalipto em função da alta intensidade de seleção. IPEF, pp. 8-17 n. $41 / 42$.

Paiva, J.R., Kageyama, P.Y., Vencovsky, R., Contel, P.B., 1994. Genetics of rubber tree (Hevea brasiliensis (Willd. ex Adr: de Juss) Müll. Arg.) I. Genetic variation in natural populations. Silvae Genetica 43 (5/6), 307-312.

Pereira, A.V., Pereira, E.B.C., 2001. Cultura da seringueira no cerrado. Embrapa Cerrados, Planaltina $59 \mathrm{p}$.

Pereira, M.B., Vencovsky, R., 1988. Limites da seleção recorrente. I. Fatores que afetam o acréscimo das frequiências alélicas. Pesquisa Agropecuária Brasileira 23, 769-780.

Pimentel-Gomes, F., Garcia, C.H., 2002. Estatística aplicada a experimentos agronômicos e florestais: exposição com exemplos e orientações para uso de aplicativos. FEALQ, Piracicaba $309 \mathrm{p}$

Resende, M.D.V., 1995. Delineamento de experimentos de seleção para maximização da acurácia seletiva e do progresso genético. Revista Árvore 19 (4), 479-500.

Resende, M.D.V., 2002. Genética biométrica e estatística no melhoramento de plantas perenes. Embrapa Informação Tecnológica, Brasília 975 p.

Resende, M.D.V., 2004. Métodos estatísticos ótimos na análise de experimentos de campo, vol. 1 Embrapa Floresta, Colombo 57 p.

Resende, M.D.V., 2007a. Matemática e estatística na análise de experimentos e no melhoramento genético. Embrapa Florestas, Colombo 561 p.

Resende, M.D.V., 2007b. SELEGEN-REML/BLUP: sistema estatístico e seleção genética computadorizada via modelos lineares mistos. Embrapa Florestas, Colombo 359 p.

Resende, M.D.V., 2016. Software Selegen-REML/BLUP: a useful tool for plant breeding. Crop Breed. Appl. Biotechnol. 16, 330-339.

Resende, M.D.V., Duarte, J.B., 2002. Precisão e controle de qualidade em experimentos de avaliação de cultivares. Pesquisa Agropecuária Tropical 37 (3), 182-194.

Resende, M.D.V., Fernandes, J.S.C., 1999. Procedimento BLUP individual para delineamentos experimentais aplicados ao melhoramento florestal. Revista de Matemática e Estatística 17, 87-109.

Resende, M.D.V., Higa, A.R., 1994. Maximização da eficiência da seleção em testes de progênies de Eucalyptus através da utilização de todos os efeitos do modelo matemático. Boletim de Pesquisa Florestal 28/29, 37-55.

Santos, W., Souza, D.C.L., Moraes, M.L.T., Aguiar, A.V., 2016. Genetic variation of wood and resin production in Pinus caribaea var. hondurensis Barret \& Golfari. Silvae Genetica 65, 31-37.

Silva, J.M., Aguiar, A.V., Mori, E.S., Moraes, M.L.T., 2011. Variação Genética e ganho esperado na seleção de progênies de Pinus caribaea var. caribaea em Selvíria, MS. Scientia Forestalis 39 (90), 241-252.

Silva, G.A.P., Gouvêa, L.R.L., Verardi, C.K., Resende, M.D.V., Scaloppi Junior, J.E., Gonçalves, P.S., 2012. Parâmetros genéticos e da correlação em ciclos de medição início em seringueiras. Euphytica 189, 625-634.

Souza, A.M.D., Gouvêa, L.R.L., Oliveira, A.L.B., Silva, G.A.P., Gonçalves, P.S., 2017. Estimates of genetic parameters for the rubber yield and secondary traits in rubber tree. Ind. Crops Prod. 98, 19-24.

Sturion, J.A., Resende, M.D.V., 2010. Avaliação do delineamento experimental utilizado em teste de progênie de erva-mate. Comunicado técnico 249: Embrapa Florestas.

Tung, E.S.C., Freitas, M.L.M., Florsheim, S.M.B., Lima, I.L., Longui, E.L., Santos, F.W., Moraes, M.L.T., Sebbenn, A.M., 2010. Variação genética para caracteres silviculturais e anatômicos da madeira em progênies de Myracrodruon urundeuva (Engler) Fr. Allem. Scientia Forestalis 38 (87), 499-508.

Vencosvsky, R., Barriga, P., 1992. Genética biométrica no fitomelhoramento. Sociedade Brasileira de Genética, Ribeirão Preto 496 p.

Verardi, C.K., Scaloppi Junior, E.J., Gonçaves, P.S., 2011. Prediction of direct and indirect genetic gains and genotypic correlations in rubber tree progenies. Pesquisa Agropecuária Brasileira 46 (9), 1076-1081.

Verardi, C.K., Scaloppi Junior, E.J., Silva, G.A.P., Gouvêa, L.R.L., Gonçalves, P.S., 2013 Genetic parameters and estimated genetic gains in young rubber tree progênies. Pesquisa agropecuária brasileira 48 (4), 411-416.

Verardi, C.K., Oliveira, A.L.B., Silva, G.A.P., Gouvêa, L.R.L., Gonçalves, P.S., 2014. Comparison between different selection methods of rubber trees. Ind. Crops Prod. 52, 255-263.

Wei, R.P., Lindgren, D., 1996. Effective family number following selection with restrictions. Biometrics 52 (1), 198-208. 